\title{
Baltic salmon activates immune relevant genes in fin tissue when responding to Gyrodactylus salaris infection
}

\author{
Per Kania ${ }^{1}$, Thomas B. Larsen ${ }^{1}$, Hans C. Ingerslev ${ }^{2}$, Kurt Buchmann ${ }^{1, *}$ \\ ${ }^{1}$ Department of Veterinary Pathobiology, Laboratory of Fish Diseases, Faculty of Life Sciences, University of Copenhagen, \\ Stigbøjlen 7, 1870 Frederiksberg C, Denmark \\ ${ }^{2}$ Department of Biology, University of Bergen, Thormøhlensgate 55, 5020 Bergen, Norway
}

\begin{abstract}
Immune mechanisms in 2 strains of Salmo salar (Baltic salmon from River Ume Älv in Sweden and East Atlantic salmon from River Skjernå in Denmark) infected with the monogenean ectoparasite Gyrodactylus salaris were elucidated by molecular tools (real-time PCR). The gene expression in the fins (the preferred microhabitat of the parasite) of the susceptible but responding Swedish salmon was compared to the expression in the fins of the highly susceptible and nonresponding East Atlantic salmon. Experimental infections confirmed that both the Swedish and the Danish salmon allowed initial propagation of the parasite on the fins for a few weeks. Baltic salmon subsequently activated a response from Day 28 and limited the parasite population to a few parasites per host within the following weeks. In contrast, the Danish salmon did not respond and experienced a continuing increase in the parasite load during the same period, which reached several hundreds of parasites per host. RNA was isolated from fins of the 2 salmon strains during the course of infection and subsequent real-time PCR showed an increased expression of INF,$M x$ and MHC I genes in Baltic salmon fins during large segments of the response phase. No upregulation of these genes could be detected in susceptible salmon. No increase in immunoglobulin genes was seen in any of the fish strains, which supports the notion that antibodies are not involved in the response. Further, the work suggests that cellular factors could at least partly contribute to the anti-parasitic response in Baltic salmon
\end{abstract}

KEY WORDS: Host response $\cdot$ Real-time PCR $\cdot$ Salmon $\cdot$ Gyrodactylus salaris

Resale or republication not permitted without written consent of the publisher

\section{INTRODUCTION}

A series of studies have documented a superior ability of several strains of Baltic salmon to respond to and limit infections of the ectoparasitic monogenean Gyrodactylus salaris. In contrast, a range of East Atlantic strains of salmon are highly susceptible and do not activate effective anti-parasitic responses against this particular parasite (Bakke et al. 1990, Bakke \& MacKenzie 1993, Malmberg 1993, Dalgaard et al. 2003, 2004, Heinecke \& Buchmann 2006, Lindenstrøm et al. 2006). The response patterns of fish against gyro- dactylids can be divided into 3 groups: (1) innately resistant, (2) susceptible but finally responding and (3) susceptible with no activation of responses (Bakke et al. 2002). Theoretically a series of immunological effector mechanisms (both humoral and cellular) could be involved in the response of a fish host against monogeneans (Buchmann 1999, Buchmann \& Lindenstrøm 2002), but experimental evidence on this topic is limited. Lindenstrøm et al. (2006) found that susceptible Scottish salmon overexpressed interleukin-1 $\beta$ (IL-1 $\beta$ ), in the skin during the initial phase of $G$. salaris infections compared to less susceptible Baltic salmon. 
This was interpreted as an inappropriate response because the cytokine-induced mucus secretion merely favoured the propagation of the parasites, which suggested that one or more other factors participate in the final elimination of parasites in the responding Baltic salmon. Further, Collins et al. (2007) recognised the gene for FIP2 to be upregulated in susceptible salmon upon infection but the exact function of the gene is still to be determined. In the present work we present evidence that genes associated with cellular responses such as INF $\gamma, M x$ and $M H C I$ are expressed during the response phase of Baltic salmon, but not in East Atlantic salmon, whereas no evidence for involvement of immunoglobulin could be detected in any of the strains.

\section{MATERIALS AND METHODS}

Fish. East Atlantic salmon eggs from the Danish River Skjernå were hatched and fry reared to the age of $4 \mathrm{mo}$ at the Danish Center for Wild Salmon, Jutland, and subsequently brought to the experimental university facility, University of Copenhagen, Frederiksberg. Baltic salmon eggs from the River Ume Älv in Sweden were hatched at this university facility and fry were kept for 4 mo until experimentation. The 2 fish groups had body lengths of 4 to $6 \mathrm{~cm}$. All fish were acclimatised in four $120 \mathrm{l}$ tanks for $1 \mathrm{wk}$ before the experiment.

Parasites. A laboratory stock of the Norwegian form of Gyrodactylus salaris from the River Lærdalselva was propagated in our laboratory on Scottish salmon for 4 yr before experimentation.

Water and fish tanks. The water used was a 50:50 mixture of deionised water and municipal water (Frederiksberg County), which was dechlorinated and kept aerated for $1 \mathrm{wk}$ before use. The $120 \mathrm{l}$ tanks were kept aerated and with internal biofilters (Eheim) in thermostat controlled rooms at 12 to $13^{\circ} \mathrm{C}$ with a $12 \mathrm{~h}$ light:12 h dark cycle.

Experimental design. A total of 240 salmon divided into 4 groups (2 experimental and 2 control tanks) were used for the experiment. Thus, 120 salmon were exposed to parasites. This was done by subjecting a group of 60 River Ume Älv fish to 3000 parasites for $24 \mathrm{~h}$ and a group of 60 River Skjernå fish to 3000 live parasites. The infection was performed by placing the fish with infected salmon fins carrying parasites in 1201 aquaria with lowered water levels. Another 120 fish $(2 \times 60$ control fish) were kept and handled similarly, but without inducing infection (sham infection with uninfected fins).

Parasite counting. Subsamples (5 specimens) of fish in all 4 groups were examined weekly. Following anaesthesia of fish in MS-222 (50 $\left.\mathrm{mg} \mathrm{l}^{-1}\right)$ the parasites were counted on all body regions (Buchmann \& Uldal 1997) under a dissection microscope ( 7 to $40 \times$ magnification). The infection level was expressed as mean intensity (mean number of parasites per infected fish).

Sampling for molecular analysis. At Days 0, 1, 14, $21,28,35$ and 42 a total of 5 individuals from each tank were sampled for molecular analysis. This was done before sampling for parasite counting was performed to prevent any effect on gene expression due to handling. Fish were anaesthetised and killed in MS-222 $\left(200 \mathrm{mg} \mathrm{l}^{-1}\right)$. Fin tissue samples cut immediately from the individual fish were conserved in RNAlater ${ }^{\mathrm{TM}}$ (Sigma).

Isolation of RNA and cDNA synthesis. RNA was isolated from sonicated fin tissue with GenElute ${ }^{\mathrm{TM}}$ Total RNA kit (Sigma). Removal of genomic DNA was conducted with Deoxyribonuclease I (Sigma) and finally the quality was checked with $1 \%$ agarose electrophoresis of $2 \mu \mathrm{l}$ of the RNA. An amount of $400 \mathrm{ng}$ RNA was used in each $20 \mu$ reaction for cDNA synthesis with TaqMan ${ }^{\circledR}$ Reverse Transcription Reagents (Applied Biosystems). The cDNA was diluted by addition of $180 \mu \mathrm{l}$ RNase-free water.

Real-time quantitative PCR (RQ-PCR). A total of $2.5 \mu \mathrm{l}$ of the diluted cDNA was used as template in a $12.5 \mu \mathrm{l}$ RQ-PCR reaction using Jumpstart ${ }^{\mathrm{TM}}$ taqReadyMix $^{\text {TM }}$ (Sigma cat. no. D7440) in the Mx3000P ${ }^{\text {TM }}$ realtime PCR system (Stratagene). Cycle conditions for all reactions were 1 cycle of pre-denaturation at $94^{\circ} \mathrm{C}$ for $2 \mathrm{~min}$, and 40 cycles with denaturation at $94^{\circ} \mathrm{C}$ for $30 \mathrm{~s}$. Annealing and elongation were in 1 step at $60^{\circ} \mathrm{C}$ for 1 min with endpoint measurement. Expression analyses were performed for the immune relevant genes encoding INF $\gamma$ (GenBank accession number AY795563), CD8 $\alpha$ (GenBank accession number AY693393), Mx isoforms 1, 2 and 3 (GenBank accession numbers for Mx1: U66475, Mx2: U66476, Mx3: U66477), MHC I (conserved region of 10 sequences presented by Grimholt et al. 2002) and IgM (GenBank accession number S48658). Primers, probes (designed from the above mentioned sources) and $\mathrm{MgCl}_{2}$ concentrations used are listed in Table 1. Elongation Factor $\alpha 1$ (GenBank accession number AF321836) was used as the housekeeping gene as it has been shown to be the least regulated gene amongst several others (Ingerslev et. al. 2005).

Analysis of RQ-PCR data. Data were analyzed according to the $2^{-\Delta \Delta C t}$ method by Livak \& Schmittgen (2001). Change in threshold cycle number $\left(\Delta C_{t}\right)$ was calculated as the difference in the $C_{t}$ between the target gene and the housekeeping gene for each individual. The means of the control groups (uninfected groups for each sampling point for each salmon strain) were calculated. For each salmon strain the $\Delta \Delta \mathrm{C}_{\mathrm{t}}$ 
Table 1. Primers, probes and applied $\mathrm{MgCl}_{2}$ concentrations used in the reactions for detection of gene expression in fins of salmon using real-time PCR

\begin{tabular}{|c|c|c|c|c|}
\hline Gene & Probe $\left(5^{\prime}-3^{\prime}\right)$ & Forward $\left(5^{\prime}-3^{\prime}\right)$ & Reverse $\left(5^{\prime}-3^{\prime}\right)$ & $\begin{array}{c}\mathrm{MgCl}_{2} \\
(\mathrm{mM})\end{array}$ \\
\hline$C D 8 \alpha$ & CAACTCGACTTGCTGGGCCA & AATCAATGGTAACGCGCTTG & TGGCTGTGGTCATTGGTGTA & 3.5 \\
\hline$I F N \gamma$ & TTGATGGGCTGGATGACTTTAGGA & AAGGGCTGTGATGTGTTTCTG & TGTACTGAGCGGCATTACTCC & 5.5 \\
\hline $\operatorname{Ig} M$ & ACCGACAGGGACAGCATGGG & ACTGTCCATGCAGCAACACC & СТCCAACGCCATACAGCAGA & 3.5 \\
\hline MHC I & TGGTGTCCTGGCAGAAAGACGG & GCGACAGGTTTCTACCCCAGT & TGTCAGGTGGGAGCTTTTCTG & 3.5 \\
\hline$M x 1,2,3$ & CAACTGGAGGAACCAGCAGTCAAGA & TTGAGGTGATGGTGAAAGACC & GCTCTGAGCCAGCAGTAAGAA & 5.5 \\
\hline
\end{tabular}

values were then calculated as the difference between the $\mathrm{C}_{\mathrm{t}}$ of the infected individual and the average of the uninfected group at the sampling point. $\Delta \Delta C_{t}$ values for each group at each sampling point were averaged and standard deviation calculated before calculating folds as $2^{-\Delta \Delta \mathrm{Ct}}$. The $95 \%$ confidence intervals of the fold value was then calculated according to Livak \& Schmittgen (2001). If the fold value was $>1$, the fold was denoted as a fold increase (positive values); if it was $<1$, the negative reciprocal was calculated and the result denoted as a fold decrease (negative values), and if the fold value was equal to 1, the target gene was considered unregulated. The Mann-Whitney $U$-test was used to detect differences between groups using a 5\% probability level.

\section{RESULTS}

The infection level of Gyrodactylus salaris on the 2 salmon strains followed the same course for the first 4 wk post-infection (p.i.). However, the parasite load on Baltic salmon from River Ume Älv fell drastically during the following $3 \mathrm{wk}$ to a few parasites per host at Day 42. In contrast, the parasite population on the East Atlantic River Skjernå salmon increased markedly to several hundred parasites per fish during this period (Table 2). When a number of genes in fin tissue from the 2 salmon strains were tested for regulation during the course of infection, the responding Baltic salmon showed upregulation of the genes encoding INF $\gamma, \mathrm{Mx}$ proteins, CD8 $\alpha$ and MHC I during large parts of the period (Table 3). INF $\gamma$ was generally (but not significantly) downregulated in River Skjernå salmon. In contrast this gene was upregulated in Ume Älv salmon from Days 14 to 35. $M x$ genes were also upregulated in River Ume Älv salmon at Day 28. The gene encoding CD8 $\alpha$ was generally weakly (and nonsignificantly) downregulated in Danish salmon in contrast to a weak but not significant upregulation in Swedish salmon. Both fish strains showed a nonsignificant upregulation of CD8 $\alpha$ at Day 42. The MHC I gene was generally upregulated in River Ume Älv salmon with significant values at Days 14 and 42. No regulation of immunoglobulin genes were detected in any of the strains (Table 3 ).

\section{DISCUSSION}

The notion that at least most of the Baltic strains of Atlantic salmon, with one exception (Bakke et al. 2004), are less susceptible to Gyrodactylus salaris infection compared to the East Atlantic strains (Bakke et al. 1990, Bakke \& MacKenzie 1993, Dalgaard et al. 2003, 2004, Lindenstrøm et al. 2006, Heinecke \& Buchmann 2006) is supported by the present investigation. This study showed a clear antiparasitic response in River Ume Älv salmon after 4 wk of infection, whereas the Danish River Skjernå salmon from the western part of Denmark exhibited a continous increase in the parasite load during the entire period. The mechanisms involved in the response have not been finally resolved. An inappropriate (and possibly parasite-promoting) hyperactivation of $I L-1 \beta$ genes in susceptible Scottish salmon was found by Lindenstrøm et al. (2006) and

Table 2. Gyrodactylus salaris infecting Salmo salar. Course of infection in River Skjernå salmon (East Atlantic strain) and River Ume Älv salmon (Baltic strain) during $42 \mathrm{~d}$ post-infection. Data are expressed as number of parasites per fish (mean $\pm \mathrm{SD}$ ) (5 fish per sample). Values in bold indicate significant differences $(\mathrm{p}<0.05)$ between the 2 strains (Mann-Whitney $U$-test)

\begin{tabular}{|c|c|c|c|c|c|c|c|}
\hline & Day 1 & Day 7 & Day 14 & Day 21 & Day 28 & Day 35 & Day 42 \\
\hline River Skjernå & $20.2 \pm 14.3$ & $15.6 \pm 12.1$ & $26.8 \pm 13.3$ & $44.0 \pm 19.3$ & $75.0 \pm 18.4$ & $248.3 \pm 35.8$ & $326.7 \pm 163.8$ \\
\hline River Ume Älv & $12.8 \pm 10.4$ & $20.2 \pm 11.2$ & $34.6 \pm 15.8$ & $54.6 \pm 11.9$ & $72.4 \pm 29.3$ & $24.4 \pm 13.5$ & $5.2 \pm 1.8$ \\
\hline
\end{tabular}


Table 3. Gyrodactylus salaris infecting Salmo salar. Gene expression in fins of Swedish (Baltic strain) and Danish (East Atlantic strain) salmon during infection with G. salaris. Values are given as fold increase or decrease, with $95 \%$ confidence intervals in brackets (5 fish per sample). Values in bold designate significant difference $(\mathrm{p}<0.05)$ from control groups within the same hoststrain (Mann-Whitney $U$-test)

\begin{tabular}{|c|c|c|c|c|c|c|c|c|}
\hline Gene & Strain & Day 0 & Day 1 & Day 14 & Day 21 & Day 28 & Day 35 & Day 42 \\
\hline$C D 8 \alpha$ & $\begin{array}{l}\text { River Skjernå } \\
\text { River Ume Älv }\end{array}$ & $\begin{array}{l}-1.4[-4.4 ; 2.3] \\
+1.8[-1.1 ; 3.7]\end{array}$ & $\begin{array}{l}+1.7[-1.4 ; 4.2] \\
+2.0[-1.1 ; 4.3]\end{array}$ & $\begin{array}{l}+1.0[-3.1 ; 3.3] \\
+3.2[1.7 ; 5.9]\end{array}$ & $\begin{array}{l}-1.7[-3.7 ; 1.3] \\
+1.3[-1.1 ; 2.0]\end{array}$ & $\begin{array}{l}-1.0[-1.7 ; 1.7] \\
-1.1[-3.1 ; 2.4]\end{array}$ & $\begin{array}{l}-1.5[-2.6 ; 1.1] \\
+1.6[-1.0 ; 2.4]\end{array}$ & $\begin{array}{l}+3.7[1.7 ; 7.9] \\
+5.2[1.2 ; 22.4]\end{array}$ \\
\hline$I N F \gamma$ & $\begin{array}{l}\text { River Skjernå } \\
\text { River Ume Älv }\end{array}$ & $\begin{array}{l}-1.8[-4.7 ; 1.5] \\
-1.0[-2.1 ; 1.9]\end{array}$ & $\begin{array}{l}-2.5[-5.5 ;-1.1] \\
+1.4[-2.6 ; 5.4]\end{array}$ & $\begin{array}{r}+1.2[-3.3 ; 5.0] \\
+\mathbf{1 1 . 5}[4.5 ; 29.4]\end{array}$ & $\begin{array}{l}+1.2[-1.8 ; 2.4] \\
+\mathbf{5 . 3}[3.4 ; 8.1]\end{array}$ & $\begin{array}{l}+2.0[1.1 ; 3.4] \\
+4.0[-1.3 ; 20.2]\end{array}$ & $\begin{array}{l}-1.5[-1.8 ;-1.2] \\
+3.2[1.6 ; 6.5]\end{array}$ & $\begin{array}{l}+1.6[-1.1 ; 2.9] \\
-1.2[-3.4 ; 2.5]\end{array}$ \\
\hline $\operatorname{Ig} M$ & $\begin{array}{l}\text { River Skjernå } \\
\text { River Ume Älv }\end{array}$ & $\begin{array}{l}+1.6[-1.0 ; 2.4] \\
+1.4[-1.1 ; 2.0]\end{array}$ & $\begin{array}{l}-1.1[-2.2 ; 1.8] \\
-1.1[-1.5 ; 1.3]\end{array}$ & $\begin{array}{l}+1.2[-2.0 ; 2.9] \\
-1.3[-3.0 ; 1.8]\end{array}$ & $\begin{array}{l}-1.2[-2.1 ; 1.4] \\
+1.1[-1.5 ; 1.8]\end{array}$ & $\begin{array}{l}+1.3[-1.2 ; 2.0] \\
-1.8[-4.2 ; 1.4]\end{array}$ & $\begin{array}{l}-1.9[-2.6 ;-1.3] \\
+\mathbf{1 . 2}[-1.2 ; 1.6]\end{array}$ & $\begin{array}{l}-1.2[-1.3 ;-1.1] \\
-1.6[-1.9 ;-1.4]\end{array}$ \\
\hline MHC I & $\begin{array}{l}\text { River Skjernå } \\
\text { River Ume Älv }\end{array}$ & $\begin{array}{l}-1.5[-2.5 ; 1.2] \\
+1.0[-1.6 ; 1.6]\end{array}$ & $\begin{array}{l}-1.7[-4.2 ; 1.5] \\
+2.5[-1.1 ; 6.8]\end{array}$ & $\begin{array}{l}-1.7[-2.8 ; 1.0] \\
+\mathbf{5 . 7}[2.7 ; 12.0]\end{array}$ & $\begin{array}{l}-1.2[-1.9 ; 1.3] \\
+1.9[-1.1 ; 3.7]\end{array}$ & $\begin{array}{l}-1.0[-1.3 ; 1.3] \\
+2.2[1.1 ; 4.2]\end{array}$ & $\begin{array}{l}+1.2[-1.4 ; 1.9] \\
+2.2[-1.2 ; 6.1]\end{array}$ & $\begin{array}{l}+1.3[1.2 ; 1.5] \\
+4.7[1.9 ; 11.4]\end{array}$ \\
\hline$M x 1,2,3$ & $\begin{array}{l}\text { River Skjernå } \\
\text { River Ume Älv }\end{array}$ & $\begin{array}{l}+1.3[-1.6 ; 2.5] \\
-1.3[-2.7 ; 1.6]\end{array}$ & $\begin{array}{l}-2.5[-5.5 ;-1.1] \\
+1.5[-1.2 ; 2.6]\end{array}$ & $\begin{array}{l}+1.2[-1.7 ; 2.5] \\
+1.3[-1.3 ; 2.3]\end{array}$ & $\begin{array}{l}-1.8[-2.5 ;-1.3] \\
+2.5[-1.5 ; 9.3]\end{array}$ & $\begin{array}{l}-1.3[-1.8 ; 1.0] \\
+\mathbf{5 . 0}[2.6 ; 9.6]\end{array}$ & $\begin{array}{l}+1.6[1.2 ; 2.1] \\
+2.5[1.2 ; 5.3]\end{array}$ & $\begin{array}{l}+1.6[1.4 ; 1.8] \\
+2.2[1.1 ; 4.3]\end{array}$ \\
\hline
\end{tabular}

a similar role of the FIP2 gene has been suggested by Collins et al. (2007). However, the decisive factors which reduce the parasite population on the fish fins (the main microhabitat of G. salaris, Heinecke \& Buchmann 2006) remain unknown. The gene expression results shown here indicate that the genes encoding INF $\gamma, M x$, and MHC I could play a role. These genes were found upregulated in the responding Baltic salmon at least during part of the period when the parasite population decreased on the hosts. Expression of genes encoding INF $\gamma$ (T-cell produced cytokine) especially suggests that T-cell-like reactivity takes part in the reaction against G. salaris. Thus, INF $\gamma$ is known to be produced by activated T-lymphocytes and natural killer (NK)-cells and enhances the expression of MHC I (markers for nucleated cells), and promotes CD8 positive T-cell responses and induces production of $\mathrm{Mx}$ proteins (Goodburn et al. 2000). Therefore, the results of this study could either be explained by immigration of T-cells, T-cell equivalents or NK-cells from the vascular system to the infected fin epidermis or could be interpreted as increased expression of resident T-cells or NK-cells in fin tissue. This would result in a relatively higher presence of RNA encoding INF $\gamma, \mathrm{Mx}$ and MHC I. No regulation of immunoglobulin production in any of the fish strains was found following infection, and this supports the immunochemical work by Buchmann et al. (2004) that showed (using western blot techniques) that no increased specific immunoglobulin production in salmon skin could be found after $G$. salaris infection. A number of other immune relevant genes including those encoding the T-cell receptor (alpha chain), IL-10, MHCII and CRP also were tested in this study. However, no differences (or trends towards differences) between the 2 salmon strains were found with respect to these genes (data not shown). The $I l-1 \beta$ gene was not studied in this work but should be included in future more detailed investiga- tions. Thus, the findings presented here call for further validation and extended studies of gene expression in skin and fin tissue obtained from responding and nonresponding salmon strains following infection with G. salaris. Further, the exact location of these abovementioned factors in the fin tissue (and specific cells) at various time points after infection should be determined and tools for the study of additional immune relevant genes should be developed.

Acknowledgements. The investigation was supported by the Danish Research Councils and the Danish Ministry of Environment. The authors are indebted to Dr. Tor Atle Mo, The National Veterinary Institute, Oslo, Norway, who originally provided the Lærdalselva strain of G. salaris to the senior author's laboratory.

\section{LITERATURE CITED}

Bakke TA, MacKenzie K (1993) Comparative susceptibility of native Scottish and Norwegian stocks of Atlantic salmon, Salmo salar, to Gyrodactylus salaris Malmberg: laboratory experiments. Fish Res 17:69-85

Bakke TA, Jansen PA, Hansen LP (1990) Differences in host resistance of Atlantic salmon, Salmo salar L., stocks to the monogenean Gyrodactylus salaris Malmberg, 1957. J Fish Biol 37:577-587

Bakke TA, Harris PD, Cable J (2002) Host specificity dynamics: observations on gyrodactylid monogeneans. Int J Parasitol 32:281-308

Bakke TA, Harris PD, Hansen H, Cable J, Hansen LP (2004) Susceptibility of Baltic and East Atlantic salmon Salmo salar stocks to Gyrodactylus salaris (Monogenea). Dis Aquat Org 5:171-177

Buchmann K (1999) Immune mechanisms in fish skin against monogeneans - a model. Folia Parasitol (Ceske Budejovice) $46: 1-9$

Buchmann K, Lindenstrøm T (2002) Interactions between monogenean parasites and their fish hosts. Int $\mathrm{J}$ Parasitol 32:309-319

Buchmann K, Uldal A (1997) Gyrodactylus derjavini infections in four salmonids: comparative host susceptibility and site selection of parasites. Dis Aquat Org 28:3-22 
Buchmann K, Madsen KK, Dalgaard MB (2004) Homing of Gyrodactylus salaris and G. derjavini (Monogenea) on different hosts and response post-attachment. Folia Parasitol (Ceske Budejovice) 51:263-267

Collins CM, Olstad K, Sterud E, Jones CS, Noble LR, Mo TA, Cunningham CO (2007) Isolation of a FIP2-like gene from Atlantic salmon (Salmo salar L.) found upregulated following infection with the monogenean parasite Gyrodactylus salaris Malmberg, 1957. Fish Shellfish Immunol 22:282-288

Dalgaard MB, Nielsen CV, Buchmann K (2003) Comparative susceptibility of two races of Salmo salar (Baltic Lule river and Atlantic Conon river strains) to infection with Gyrodactylus salaris. Dis Aquat Org 53:173-176

Dalgaard MB, Larsen TB, Jørndrup S, Buchmann K (2004) Differing resistance of Atlantic salmon strains and rainbow trout to Gyrodactylus salaris infection. J Aquat Anim Health 16:109-115

Goodburn S, Didcock L, Randall RE (2000) Interferons: cell signalling, immune modulation, antiviral responses and virus countermeasures. J Gen Virol 81:2341-2364

Grimholt U, Drablos F, Jorgensen SM, Hoyheim B, Stet RJM (2002) The major histocompatibility class I locus in Atlantic

Editorial responsibility: Dieter Steinhagen,

Hannover, Germany salmon (Salmo salar L.): polymorphism, linkage analysis and protein modelling. Immunogenetics 54:570-581

Heinecke R, Buchmann K (2006) Microhabitat selection of Gyrodactylus salaris in reference to susceptibility status of different salmonid strains. In: Buchmann K (ed) Diagnosis and control of fish diseases. Royal Veterinary and Agricultural University, Frederiksberg, p 21-22. Printed by Frederiksberg Bogtrykkeri, Frederiksberg

Ingerslev HC, Pettersen EF, Jakobsen RA, Petersen CB, Wergeland HI (2005) Expression profiling and validation of reference gene candidates in immune relevant tissues and cells from Atlantic salmon (Salmo salar L.). Mol Immunol 43:1194-1201

Lindenstrøm T, Sigh J, Dalgaard M, Buchmann K (2006) Skin expression of IL-1, in East Atlantic salmon, Salmo salar L., highly susceptible to Gyrodactylus salaris infection in enhanced compared to a low susceptibility Baltic stock. J Fish Dis 29:123-128

Livak K, Schmittgen TD (2001) Analysis of relative gene expression data using real-time quantitative PCR and the $2^{-\Delta \Delta C T}$ method. Methods (Orlando) 25:402-408

Malmberg G (1993) Gyrodactylidae and gyrodactylosis of salmonidae. Bull Fr Pêche Piscic 328:5-46

Submitted: November 11, 2006; Accepted: January 18, 2007 Proofs received from author(s): May 22, 2007 